\title{
Pre-Late Carboniferous geology along the contact of the Saxothuringian and Teplá-Barrandian zones in the area covered by younger sediments and volcanics (western Bohemian Massif, Czech Republic)
}

\author{
Bedřich $\mathrm{MLČOCH}^{1 *}$, Jiří KONOPÁSEK ${ }^{1,2}$ \\ ${ }^{1}$ Czech Geological Survey, Klárov 3, 11821 Prague 1, Czech Republic; bedrich.mlcoch@geology.cz \\ ${ }^{2}$ Charles University, Faculty of Science, Institute of Petrology and Structural Geology, Albertov 6, 12843 Prague 2, Czech Republic \\ * Corresponding author
}

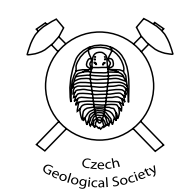

The boundary between the Saxothuringian and the Teplá-Barrandian zones at the western margin of the Bohemian Massif represents an important tectonic suture of the Central European Variscides. However, most of this boundary is covered by Late Carboniferous and younger sedimentary and volcanic rocks, which prevent direct observation of particular geological units. We present a compilation of geological and depth measurement data from 12,134 exploration boreholes that reached the basement of the volcanic and sedimentary infill in the area of the Eger Graben in the north-western Bohemia, and correlate covered geological units with those exposed on the present-day surface. The resulting compilation reveals the relief of the sedimentary basins basement and interprets the real extent of the basement geological units in the western part of the Bohemian Massif. It also shows the position of the contact between units with the Saxothuringian and the Teplá-Barrandian affinities and suggests the boundary between rocks with Devonian metamorphic record and those metamorphosed during the Early Carboniferous period of the Variscan tectonometamorphic cycle.

Keywords: Bohemian Massif, Saxothuringian Zone, Teplá-Barrandian Zone, suture, Central European Variscides Received: 17 May 2010; accepted: 7 July 2010; handling editor: J. Žák

\section{Introduction}

The contact between the Saxothuringian and the TepláBarrandian zones in the Bohemian Massif (Fig. 1) has been recognized long time ago as one of the tectonic sutures in the Central European Variscides (Kossmat 1927; Matte 1986; Franke 1989, 2000; Matte et al. 1990; Pharaoh 1999). The significance of this collisional boundary was later emphasized in numerous studies on exhumation of high-pressure rocks, which appear on both sides of the suture zone (Franke 1984; Krohe 1996; Matte 1998; Klápová et al. 1998; O’Brien 2000; Franke and Stein 2000; Willner et al. 2000; Konopásek et al. 2001; Konopásek and Schulmann 2005). However, all the tectonic interpretations are hampered by the fact that most of the transition zone between the Saxothuringian and the Teplá-Barrandian zones is covered by Late Carboniferous and Permian basin fills, Cretaceous sediments and Tertiary volcanic and sedimentary rocks of the Eger Graben (Fig. 2). Thus, with an exception of a narrow corridor in the area northwest of the Mariánské Lázně Complex (Fig. 2), the rocks along the Saxothuringian/ Teplá-Barrandian suture in the western part of the Bohemian Massif cannot be studied directly and all the data necessary for interpretation of tectonic processes must

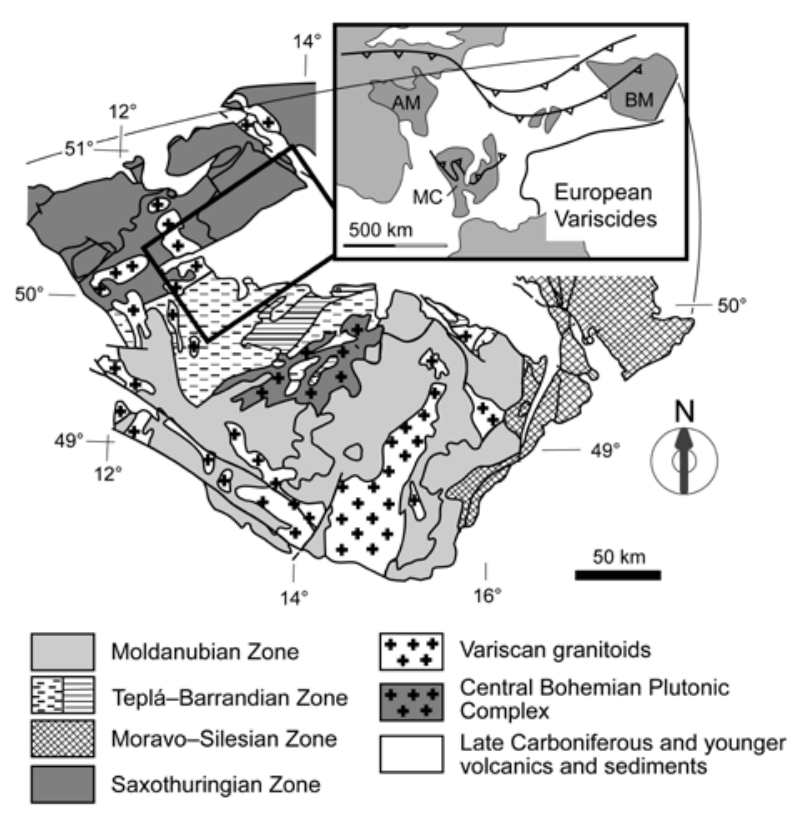

Fig. 1 Simplified geological map with major tectonic units of the Bohemian Massif. The upper inset shows the location of the Bohemian (BM) and two of the other massifs (MC - French Massif Central; AM - Armorican Massif) in the European Variscides. The area discussed in the text is represented by a black rectangle. 

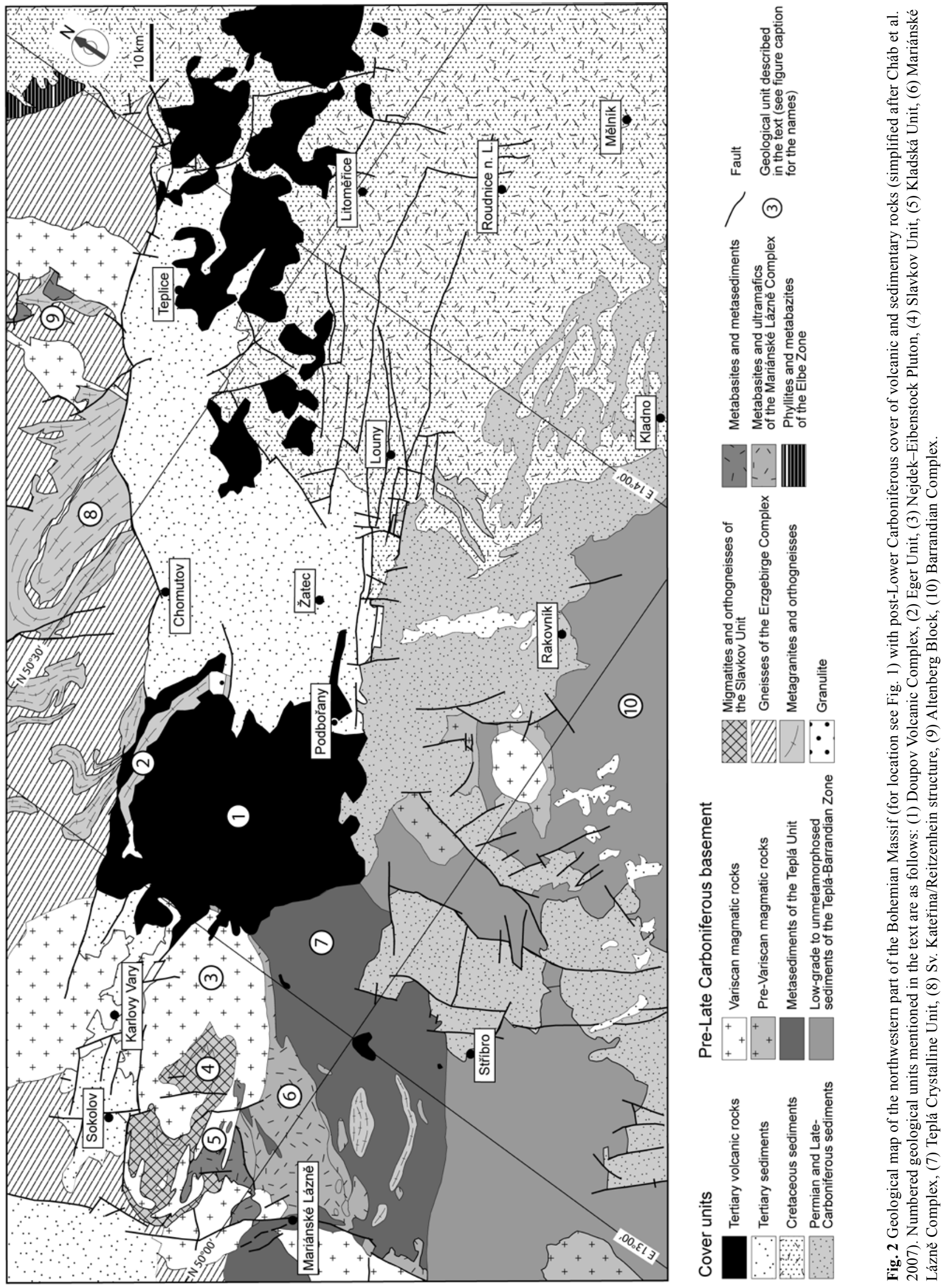
be extrapolated from observations in geological units exposed in more distal parts of the Saxothuringian and the Teplá-Barrandian zones.

Chaloupský (1973) published the first summary of available information about the basement underneath the Bohemian Cretaceous Basin in which he used a large database of exploration borehole data. His synthesis, which also partly covered the area of the Saxothuringian/TepláBarrandian boundary, was based on lithological correlations with exposed pre-Cretaceous rocks of the Bohemian Massif. At the same time, geophysical and geological observations in the Eger Graben area led to a formal definition of the surface demonstration of the Saxothuringian/Teplá-Barrandian boundary, which was then designated as the "Litoměřice deep fault" (Št'ovíčková 1973). Gravimetric survey along this fault zone has revealed a chain of positive gravity anomalies and a steep gravity gradient towards the northwest indicating the boundary between low-density rocks of the Saxothuringian Zone and high-density rocks of the Teplá-Barrandian Zone (Štovíčková 1973; Bližkovský et al. 1994; Švancara et al. 2008; Sedlák et al. 2009). Seismic survey in the area of the Saxothuringian/Teplá-Barrandian boundary by Plomerová et al. (2007) and Babuška et al. (2008) has shown differences in orientation of the mantle fabric in these large-scale zones and led to delimitation of their contact in the mantle lithosphere. The position of this boundary in the mantle was later correlated with surface geology by Babuška et al. (2007) and Babuška and Plomerová (2008). Recently, a new compilation of pre-Mesozoic geology of the Bohemian Cretaceous Basin basement was published by Uličný et al. (2009a). Their map also covers the area of the Eger Graben, but does not show the crystalline basement below the Carboniferous and Permian sediments.

We present a compilation of the data from 12,134 boreholes that reached the base of the Late Carboniferous-Cretaceous-Tertiary infill of sedimentary basins in the area southeast of the Krušné hory (Erzgebirge) Mountains. For the compilation of geological information we used archived drill cores owned by the company Diamo a.s. and the cores stored at the Czech Geological Survey. All the drill site coordinates and geological descriptions of the core samples, as well as depth measurements and geophysical data collected from boreholes during exploration drilling, are deposited at the Czech Geological Survey - Geofond (see http://www.geofond.cz/mapsphere/ EEARTH/). As an additional source of data in regions with low density of borehole data we used seismic reflection profiles of Chudomel et al. (1983). Details on early results of this work can be found in the report by Mlčoch et al. (2001).

Macroscopic and microscopic study of archive samples and samples from occasional basement exposures within the volcanosedimentary complexes permitted their lithological correlation with uncovered basement exposed at the western margin of the Bohemian Massif, namely the Erzgebirge Complex with the Eger Unit and the Kladská and Slavkov units that are all traditionally considered as a part of the Saxothuringian Zone, and the Mariánské Lázně Complex and the Teplá Crystalline Unit that are interpreted as marginal geological units of the TepláBarrandian Zone (Fig. 2). The resulting geological map was linked with existing geological maps of the surface exposures of the pre-Late Carboniferous basement (Fig. 3 ). Moreover, depth measurements in the boreholes permitted a reconstruction of the present-day surface of the basement and revealed the tectonic importance of fault structures in the development of the Late Carboniferous to Tertiary sedimentary basins.

\section{Lithological characterization of geological units identified at the base of Late Carboniferous to Tertiary sedimentary and volcanic sequences}

\subsection{The Saxothuringian Zone}

The Erzgebirge Complex shows, in its eastern part, a large orthogneiss body of the Sv. Kateřina/Reitzenhein structure (Fig. 2), which represents the structurally lowermost part of the rock sequence (Mlčoch and Schulmann 1992; Rötzler et al. 1998; Konopásek et al. 2001). Orthogneisses of the Sv. Kateřina/Reitzenhein structure are characterized by medium-temperature solid-state deformation ranging in intensity from metagranites to mylonites (Mlčoch and Schulmann 1992; Schulmann et al. 1996). The overlying metasedimentary sequence contains relicts of high-pressure/low- to medium-temperature metamorphism, corresponding to an amphibolite/ eclogite-facies transition (Rötzler et al. 1998; Konopásek 1998). Konopásek and Schulmann (2005) recognized two groups of orthogneiss bodies in the Erzgebirge Complex which are, in contrast to the Sv. Kateřina/Reitzenhein orthogneiss, overlying the high-pressure metasediments. These allochthonous bodies were subdivided into two groups according to their metamorphic conditions. The Lower Crystalline Nappe consists of medium-temperature orthogneisses without any evidence for partial melting, resembling those of the Sv. Katerina/Reitzenhein structure. These orthogneisses are associated with bodies of medium-temperature mafic eclogites (Schmädicke et al. 1992; Klápová et al. 1998; Konopásek et al. 2001). The Upper Crystalline Nappe is represented by the Eger Unit (Fig. 2) and some other orthogneiss bodies in both Czech and German parts of the central Erzgebirge (Konopásek and Schulmann 2005), where they are associated with 
high-temperature mafic eclogites (Schmädicke et al. 1992; Mlčoch et al. in press). Characteristic feature of the Upper Nappe is the dominant high-temperature metamorphism developed in felsic lithologies that had mostly igneous protoliths. It consists of high-temperature orthogneisses showing various stages of anatexis (Zulauf et al. 2002; Závada et al. 2007), granulitic gneisses and felsic granulites with subordinate migmatitic metasediments (Hradecký et al. 2000). The only surface outcrops of the Eger Unit emerge from the cover Tertiary volcanic rocks in the form of an erosive window in the Ohře River valley northeast of Karlovy Vary (Fig. 2).

In borehole samples, the identification of rocks of the Erzgebirge Complex (Fig. 3) is based on the following features: 1) Orthogneisses of the Sv. Katerina/Reitzenhein structure form direct spatial continuation of this dome known from the present-day surface. 2) Orthogneisses overlying the metasedimentary sequence represent direct continuation of allochthonous bodies west of Chomutov (Fig. 3) described by Konopásek et al. (2001) and Konopásek and Schulmann (2005). They are represented by several varieties ranging from coarse-grained types to fine-grained gneisses characterized by equigranular granulitic texture. Orthogneisses of the Lower and Upper Crystalline nappes are not distinguished in the map (Fig. 3) and we only show the granulite-bearing belt in the centre of the unit and another body of granulites that is today completely hidden below younger volcanosedimentary formations (Kopecký and Sattran 1966; Kotková 1993). 3) Metasedimentary rocks of the Erzgebirge Complex are in most cases represented by biotitemuscovite-plagioclase \pm garnet gneisses or micaschists lacking the typical medium-temperature/medium-pressure mineral assemblages with staurolite or staurolite + kyanite. 4) Northeast of the Sv. Katerrina/Reitzenhein structure, the rock sequence is dominated by feldspar-rich muscovite-biotite gneisses that are correlated with the "grey gneisses" cropping out in the northeastern part of the Erzgebirge Mts. 5) Occasional granitoid intrusions are surrounded by gneisses of the Erzgebirge Complex.

\subsubsection{The low-grade belt}

Rare exposures of low-grade rocks crop out from beneath the post-orogenic cover in the form of isolated windows in the area between Karlovy Vary and Litoměrice (Fig. 2). These rocks are represented by fine-grained phyllites, graphite-bearing quartzites and subordinate low- to medium-grade amphibolites (Sattran and Váně 1964; Mlčoch 2003). Corresponding rock association can also be seen as small denudation relicts in the Altenberg Block north-northwest of Teplice (Fig. 2) where it is interpreted as allochthonous body emplaced on top of the Erzgebirge Complex (Pietzsch 1914; Cháb et al. 2007).
Metabasites of the low-grade belt are fine-grained and bear the mineral assemblage amphibole-epidote-plagioclase-ilmenite \pm biotite \pm quartz. Fine-grained schists of this unit are usually composed of a muscovite-biotite \pm chlorite-plagioclase-quartz assemblage with occasional small relicts of garnet.

\subsection{The Teplá-Barrandian Zone}

\subsubsection{Metabasites of the Mariánské Lázně Complex}

Apart from the main body of the Mariánské Lázně Complex, equivalent rock types represented by migmatitic and banded amphibolites, serpentinites and eclogites crop out at the western flank of the Tertiary Doupov Volcanic Complex (Fig. 2) and the same rock assemblage occurs as xenoliths in the Doupov Complex volcanics. Continuation and spatial extent of the Mariánské Lázně Complex further to the northeast was inferred from the geophysical data (see references in Vrána and Štědrá 1997) and also confirmed by several boreholes.

\subsubsection{The Teplá Crystalline Unit}

The surface exposure of the Teplá Unit (Fig. 2) is represented mostly by medium-grade metasediments with well-developed Barrovian metamorphic zones (Žáček and Cháb 1993) and associated with small bodies of Cambrian granitoids (Dörr et al. 1998). A major feature serving as a basis for identification of the Teplá Unit metasediments and their discrimination from the gneisses and micaschists of the Erzgebirge Complex is the presence of Barrovian mineral assemblages with biotite, garnet, staurolite and kyanite.

Borehole samples of the Teplá Unit metasediments usually represent muscovite-biotite micaschists with occasional garnet porphyroblasts. Some of the samples are intensely deformed giving the rock a mylonitic appearance. The characteristic microscopic feature is the presence of two garnet generations and coarse-grained aggregates of kyanite crystals.

\subsubsection{The Barrandian Complex}

Rocks of the Barrandian Complex (Fig. 2) are represented by low-grade metasediments in its western part and unmetamorphosed Proterozoic-Lower Palaeozoic sedimentary sequence in the east. The Proterozoic (meta-) sedimentary sequence is intruded by bodies of Cambrian and Devonian granites (Venera et al. 2000; Dörr et al. 2002; Žák et al. in press). Core samples of the Proterozoic metasediments from the Barrandian Complex are 

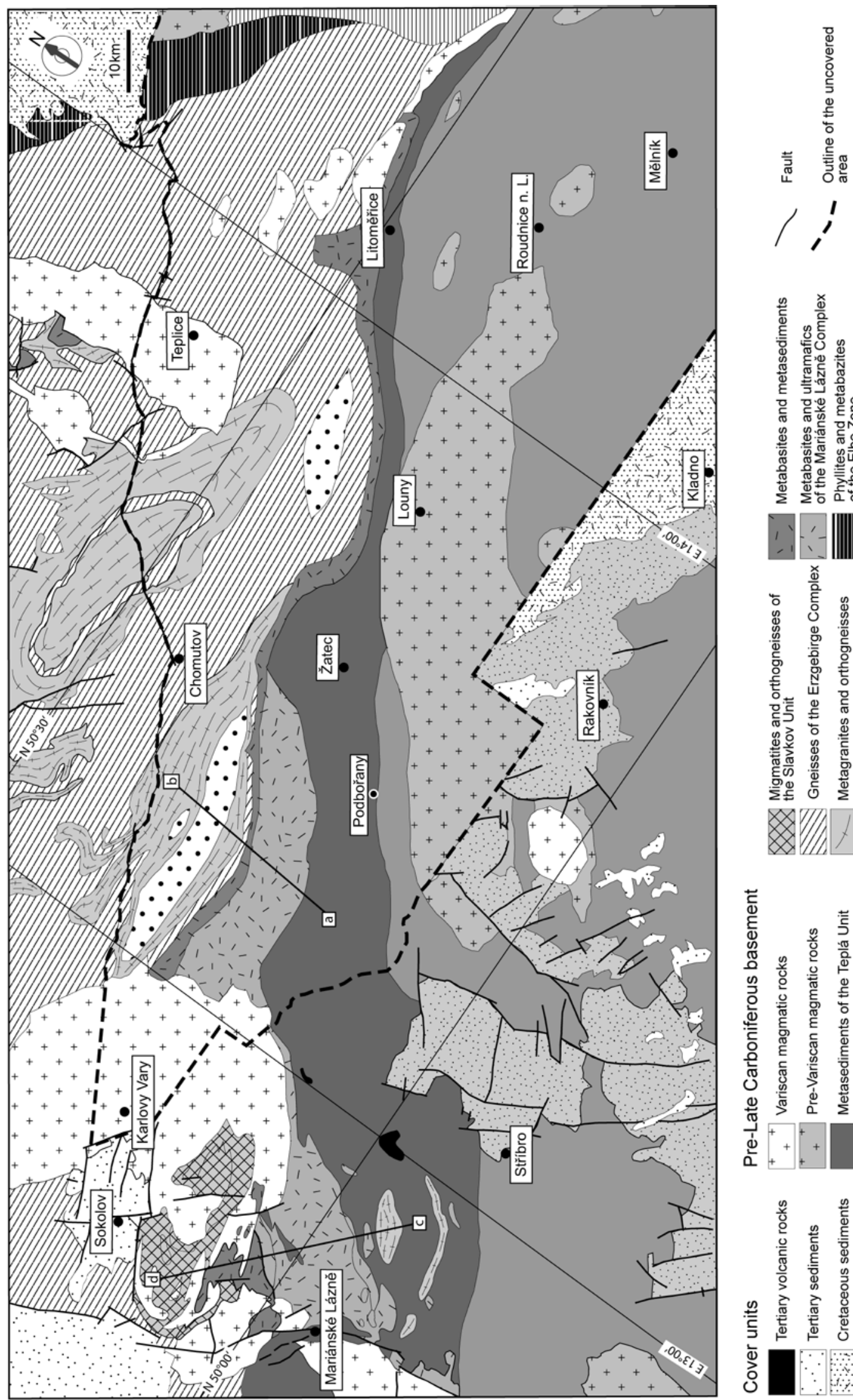

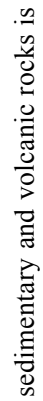

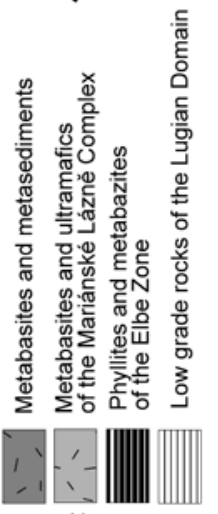

$\overrightarrow{\mathrm{s}}$
$\overline{0}$
$\overline{0}$

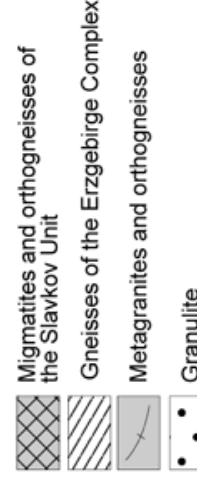

$\frac{0}{8}$

$\frac{\pi}{\frac{\pi}{0}}$

ב

这

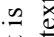

苛

苛 $\cong$

든

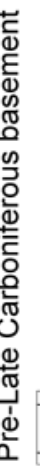

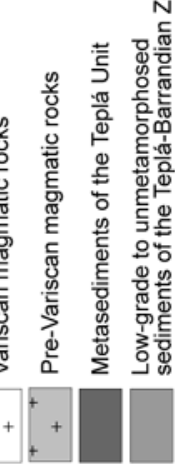

ज正

疍.

.릴 ป

हี ส

\& 8

4

苛

है 흔

है.

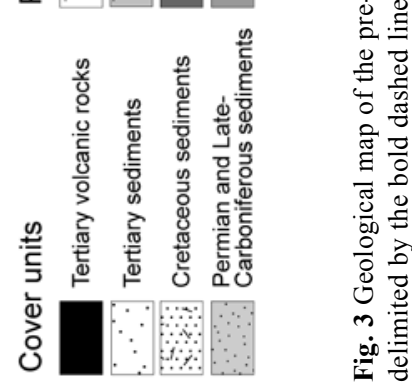


represented by fine-grained chlorite-sericite phyllites with occasional presence of low-grade metabasites. A large part of this unit in the presented map (Fig. 3) involves the granitoid body of the Louny Pluton (Mísař et al. 1983), the spatial extent of which was interpreted from the gravity data (Kopecký et al. 1997) and its presence confirmed by several boreholes.

\section{Morphology of the basement beneath the volcanic and sedimentary sequences}

Apart from the geological map, depth data from the boreholes were used for the construction of a 3D model of the crystalline basement morphology (Fig. 4) with a resolution higher than it was known from the previous studies (Chaloupský 1973). The sedimentary cover of the crystalline basement is formed by three independent systems of sedimentary basins.

The lowermost system is represented by the postorogenic infill of extensional to transtensional Carboniferous to Permian basins that largely follow the trend of the Teplá-Barrandian - Saxothuringian suture (e.g. Jindřich 1971; Malkovský 1987; Pašek and Urban 1990; Uličný et al. 2002, 2009a). As discussed e.g. in Uličný et al. (2009a), opening of this basin system was related to NE$\mathrm{SW}$ trending extensional faults. The axis of the Bohemian Cretaceous Basin follows the NW-SE striking Elbe Fault System (e.g., Uličný et al. 2009b) and cuts across the underlying Late Palaeozoic basins. However, the Elbe Fault System affected the Late Palaeozoic basins' geometry already during the Permian (Uličný et al. 2002, 2009b). The uppermost system of sedimentary basins is represented by Oligocene-Miocene infill of the Eger Rift. Špičáková et al. (2000) and Rajchl et al. (2009) have demonstrated that early opening of this basin system was governed by NNE-SSW to N-S extension oblique to the rift axis. According to these authors, major faulting occurred at a postdepositional stage and overprinted the early $\mathrm{E}-\mathrm{W}$ trending faults by NE-SW trending major bounding faults.

In the presented model of the crystalline basement morphology (Fig. 4), faults with large displacement are the most prominent, regardless of their strike or time of main activity: the NE-SW faults active as normal faults mainly during the Late Palaeozoic, NW-SE trending faults of the Elbe Fault System and, to some extent, E-W trending extensional faults. The greatest displacement occurred during the Late Palaeozoic along the NE-SW normal faults that bound individual Carboniferous-Permian basins, which can be inferred from the thickness of their infill (Pešek et al. 1998) that highly exceeds the thickness of overlying Cretaceous (Malkovský et al. 1974) and Tertiary (Malkovský 1985) sediments.
From the course of the most prominent fault structures in the presented 3D model of the crystalline basement morphology can be inferred that the Carboniferous to Permian sediments can be seen as an infill of three particular sedimentary basins, the position of which only partly overlaps with those defined by Holub and Pešek (1992). They are the Žatec Basin (western part of the Kladno-Rakovník Basin sensu Holub and Pešek 1992), the Roudnice Basin (central and eastern part of the Kladno-Rakovník Basin and the Mšeno-Roudnice Basin sensu Holub and Pešek 1992), and the Česká Kamenice Basin (Pešek et al. 1998). Holub and Pešek (1992) pointed out that their classification of Carboniferous to Permian sedimentary basins in this area is based on traditional names of coal mining districts and does not reflect the tectonosedimentary evolution. We suggest that the Žatec, Roudnice and Česká Kamenice basins are the main Late Palaeozoic structures, each of them with a distinct evolution (Mlčoch and Martínek 2002; Fig. 4). The Česká Kamenice and Roudnice basins are separated by a ridge structure along which occasional outcrops of the crystalline basement appear.

\section{Discussion}

\subsection{Spatial extent of individual geological units}

The distribution of the studied boreholes and basement outcrops at the surface (Fig. 5) shows that the best resolution of the map is reached for the basement of Cretaceous-Tertiary infill of the Eger Graben. For this reason, the extent of the Erzgebirge parautochthonous schists and gneisses, continuation of allochthonous orthogneisses and granulites and of the Sv. Kateřina/Reitzenhein structure in the central Erzgebirge, as well as the outline of the Variscan granitoid plutons are considered as a reliable picture of the subcrop on the presented map scale. On the other hand, low number of boreholes in the southern and southeastern part of the covered area may cast some doubt on the reliability of the presumed extent of some geological units. In such case, auxiliary data were used for the best possible delimitation of the subcropping units.

The areal extent of the Mariánské Lázně Complex under the cover formations is mostly inferred from the gravity survey (see gravity map and corresponding references in Vrána and Štědrá 1997). However, as discussed above, apart from several borehole data and occasional outcrops, there are also mafic xenoliths belonging to this unit enclosed in rocks of the Tertiary Doupov Volcanic Complex.

There is only a limited number of boreholes that reached the "low-grade belt" (Fig. 5). Although there are 

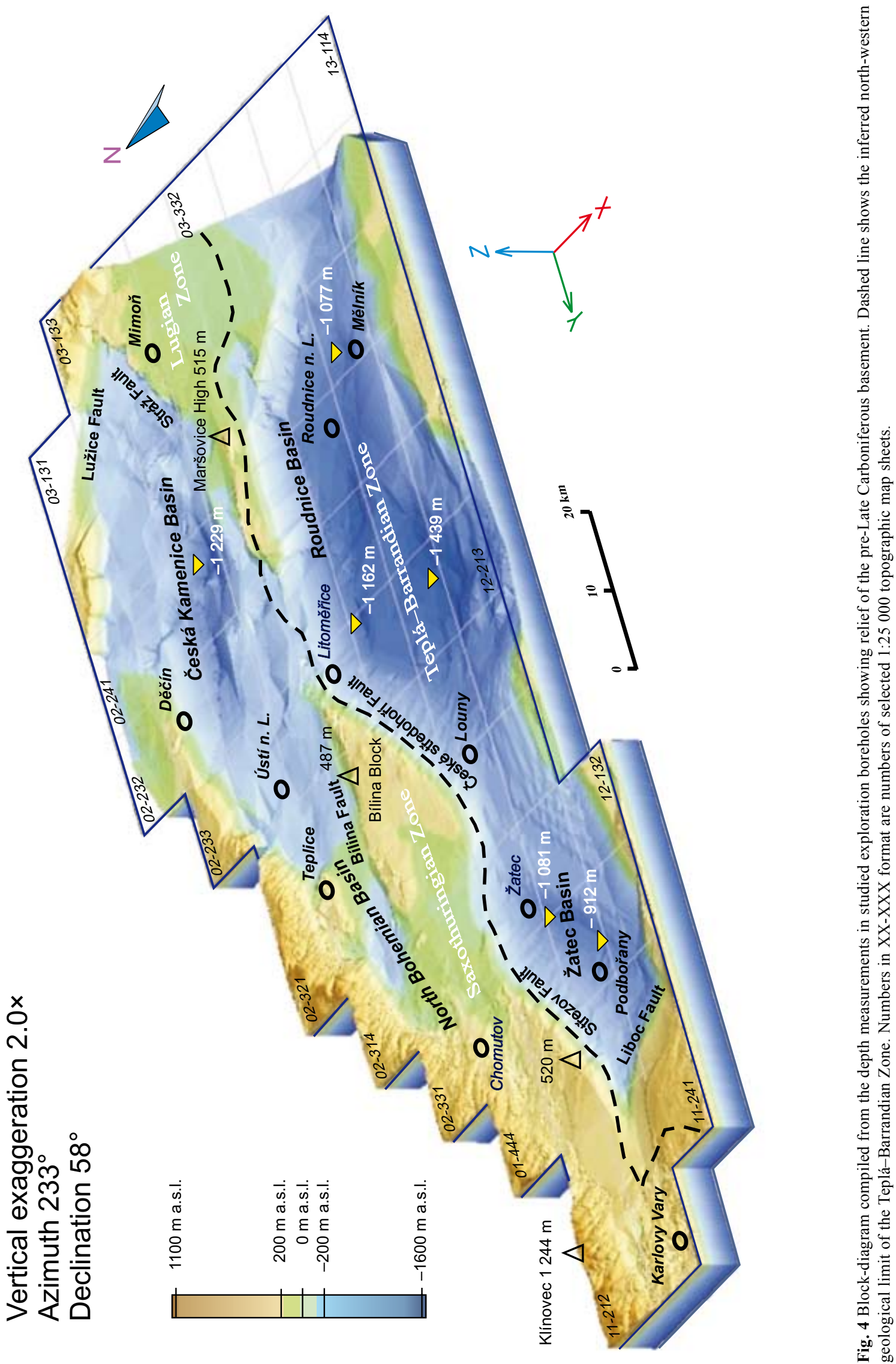


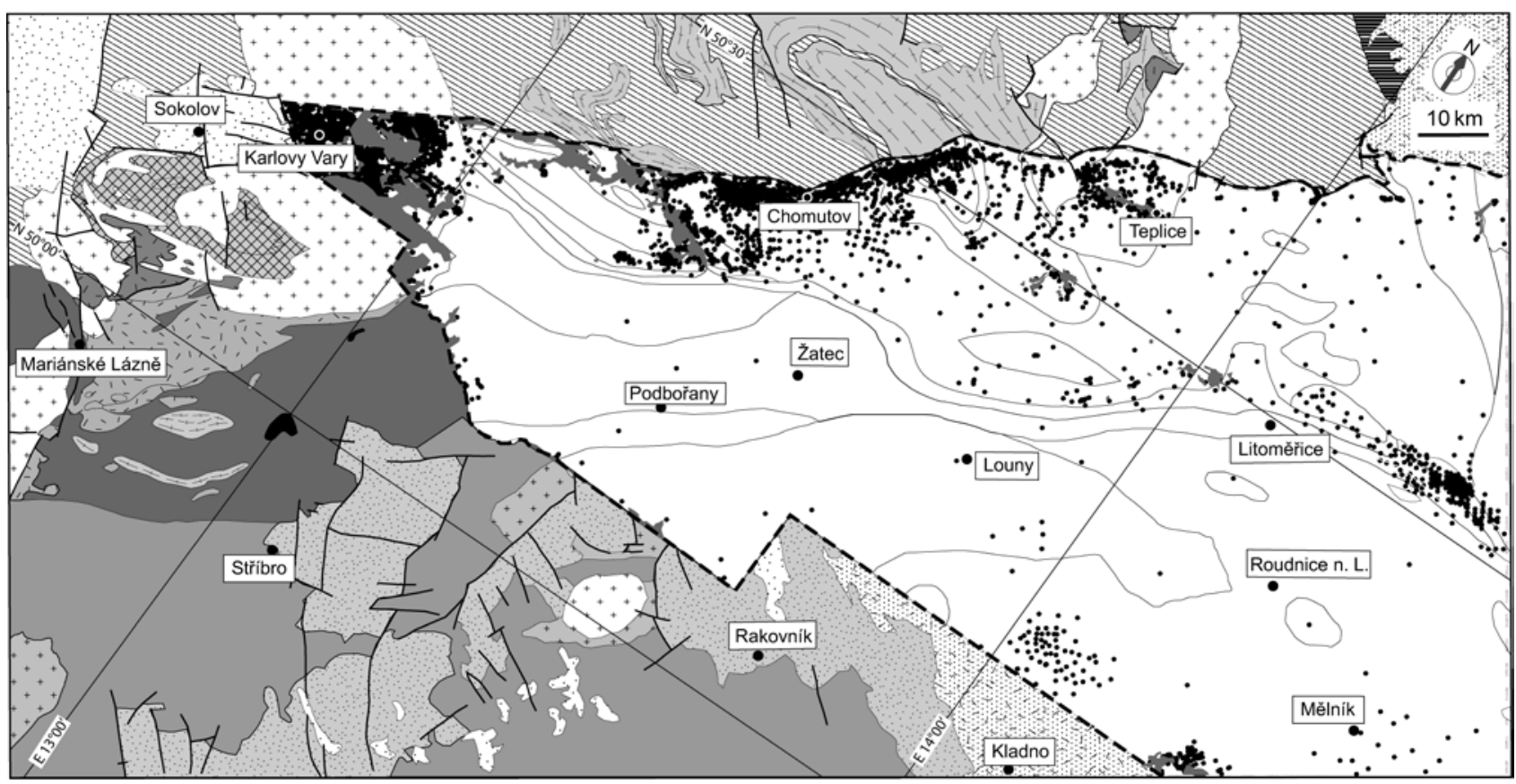

Fig. 5 Distribution of natural outcrops (grey polygons in the area delimited by the bold dashed line) and of the studied boreholes (black dots) in the area covered by the geological map of pre-Late Carboniferous basement units presented in Fig. 3. Geological units and various rock types of the pre-Late Carboniferous basement are only shown as outlines.

localities where this unit is exposed on the present-day surface and its regular presence along the margin of the Teplá-Barrandian Zone suggests that this belt could be continuous, its uninterrupted course cannot be proven with existing data. Similar is the situation with the borehole data for the continuation of the Teplá Crystalline Unit. Because the amphibolite-facies metasediments with Barrovian mineral assemblages occur along the entire exposed margin of the Teplá-Barrandian Zone (Vejnar 1982; Žáček and Cháb 1993; Zulauf 1997), except its contact with the Central Bohemian Plutonic Complex, we interpret the continuation of the Teplá Unit as an uninterrupted belt flanking the entire northwestern margin of the Teplá-Barrandian Zone.

There is a large number of boreholes in low-grade to unmetamorphosed schists of the Barrandian Complex, but they are usually concentrated in clusters. Such distribution of data cannot exclude the possibility that some other rock types (especially granitoids or metabasites) can also be present within this unit.

\subsection{Correlation of exposed and covered geological units along the Saxothuringian - Teplá-Barrandian boundary}

The presented compilation of the borehole data shows several important features of the Saxothuringian Teplá-Barrandian boundary that are directly comparable with its exposed part in western Bohemia. The mafic and ultramafic rocks of the Mariánské Lázně Complex flank approximately a half of the northwestern margin of the Teplá-Barrandian Zone. Immediately SE of the Mariánské Lázně Complex and then further to the NE, the northwestern flank of the Teplá-Barrandian Zone is represented entirely by medium- to high-grade micaschists of the Teplá Crystalline Unit, which towards the east rapidly pass into the low-grade schists. While the transition of the kyanite-sillimanite micaschists of the Teplá Crystalline Unit into migmatitic amphibolites of the Mariánské Lázně Complex can be viewed as a normal, although tectonically reduced, metamorphic gradient, there is a sharp metamorphic discontinuity along the northwestern flank of the Mariánské Lázně Complex, which is bordered by a "low-grade belt" composed of medium- to low-grade metasediments and metabasites (see geological units along the line $a-b$ in Fig. 3).

Another abrupt metamorphic transition exists to the northwest of this "low-grade belt", where it passes into a narrow belt of medium-grade gneisses, which are then in direct contact with granulite-facies mylonitic orthogneisses and migmatites of the uppermost unit of the Erzgebirge allochthon. Such sequence of metabasites, metasediments and orthogneisses is also preserved in the Altenberg Block north of Teplice (Fig. 2) and interpreted as a tectonically emplaced rock assemblage (Pietzsch 1914; Hoth et al. 1995; Schovánek et al. 2004; Cháb et al. 2007). 
This collection of geological units with different lithological content and contrasting metamorphic grades is equivalent to the rock succession further to the southwest in the area of the only exposed segment of the Teplá-Barrandian - Saxothuringian boundary (line c- $\mathrm{d}$ in Fig. 3). In the north-western tip of the Teplá-Barrandian Zone, kyanite-sillimanite metasediments of the Teplá Crystalline Unit pass into migmatitic metabasites, eclogites and ultramafic rocks of the Mariánské Lázně Complex (Žáček and Cháb 1993). In the footwall there is an assemblage of low- to medium-grade metabasites and metasediments (the Kladská Unit - Kachlík 1993) of a lithological and metamorphic character different from the overlying Mariánské Lázně Complex. The discontinuity in metamorphic grade was interpreted by Kachlík (1993) as an evidence of thrusting of the Teplá-Barrandian Zone over the Saxothuringian Belt. Further to the northwest and towards the footwall, there is another sharp metamorphic boundary, along which the above-mentioned low- to medium-grade metamorphic rocks pass into the highgrade migmatitic orthogneisses and cordierite-bearing migmatites (the Slavkov Unit - Mísař et al. 1983).

From the tectonometamorphic point of view, the assemblage of geological units and their mutual position is almost identical in both the exposed and covered parts of the discussed area. However, the presented geological map shows an apparent lateral offset between the outcropping and buried parts of the Mariánské Lázně Complex and the "low-grade belt" (Fig. 3). This offset occurs in the area of the Jáchymov Fault that was intruded by the Nejdek-Eibenstock Pluton.

The tectonometamorphic patterns suggest that going from the SE to the NW, there seems to be an increasing metamorphic grade from metasediments and orthogneisses of the Teplá Crystalline Unit towards the northwestern edge of the mafic Mariánské Lázně Complex. This gradual increase in metamorphic grade is sharply interrupted by the presence of the "low-grade belt" and the high-grade metamorphic rocks reappear as migmatitic metasediments, orthogneisses and granulites of the Erzgebirge allochthon or the Slavkov Unit.

\subsection{Age of metamorphism along the Saxothuringian - Teplá-Barrandian suture}

Existing geochronological data (Fig. 6) from the abovedescribed geological units suggest two well separated tectonic events along the Saxothuringian - Teplá-Barrandian boundary, at c. 400-360 Ma and c. 345-330 Ma. Beard et al. (1995) determined the Sm-Nd age of eclogite-facies metamorphism in the Mariánské Lázně Complex at 367 \pm 4 or $377 \pm 7$ Ma. Exhumation of the mafic rocks was dated using the $\mathrm{U}-\mathrm{Pb}$ method by analyzing zircons from amphibolites migmatitized to various extents during decompression. Bowes and Aftalion (1991) and Timmermann et al. (2004) obtained a similar age of $\sim 360$ $\mathrm{Ma}$ for the decompression melting event. The $\mathrm{K}-\mathrm{Ar}$ and Ar-Ar amphibole cooling ages show a rather large spread between 397 and $370 \mathrm{Ma}$ (Kreuzer et al. 1992; Dallmeyer and Urban 1998; Bowes et al. 2002).

Very little is known about the "low-grade belt" that flanks the northwestern margin of the Teplá-Barrandian Zone and there is no geochronological information from scarce outcrops emerging from the Cretaceous-Tertiary rocks of the Eger Graben. Several authors (Zoubek et al. 1963; Sattran and Váně 1964) interpreted the protolith age of these rocks as Palaeozoic, but this estimate is based purely on lithological correlation with rocks of that age exposed in low-grade units of the German part of the Erzgebirge. We have suggested an affinity of this belt to the low-grade unit underlying the mafic-ultramafic rocks of the exposed part of the Mariánské Lázně Complex. Metamorphic amphiboles of this low-grade unit were dated by Kreuzer et al. (1992) at $362 \pm 8 \mathrm{Ma}$, although it is not certain whether this age is valid for the entire "low-grade belt".

The adjacent migmatitic Erzgebirge allochthon shows exclusively Early Carboniferous ages of metamorphism. Granulite bodies in the Eger Unit were dated by Kotková et al. (1996) at $339 \pm 1.5$ or $346 \pm 14$ Ma using zircon and rutile geochronology and similar ages were obtained from granulite-facies rocks in the German part of the Erzgebirge Mts. (Kröner and Willner 1998; Tichomirowa et al. 2005). Zulauf et al. (2002) dated monazites and muscovites ( $\mathrm{U}-\mathrm{Pb}$ and $\mathrm{Ar}-\mathrm{Ar}$ method, respectively) from migmatitic orthogneisses of this unit and reported the same ages (within error) of $342 \pm 1 \mathrm{Ma}$ and $341 \pm$ $4 \mathrm{Ma}$, respectively. Further to the northwest, the mica cooling ages from metamorphic rocks in the Erzgebirge Complex show mostly $\sim 340$ Ma but they become slightly younger in the area of the Nejdek-Eibenstock Pluton and in the northern part of the Sv. Kateřina/Reitzenhein structure (Werner and Lippolt 2000). These data in combination with presented geological map suggest that the "chronometamorphic" boundary between the areas of Devonian and Early Carboniferous metamorphism could be represented by the transition from the low-grade metamorphic units underlying the Mariánské Lázně Complex and the medium-grade metasediments of the Teplá Unit into the units bearing granulite-facies orthogneisses, migmatites and granulites (Fig. 6).

\subsection{The Saxothuringian - Teplá-Barrandian boundary}

Our evaluation of the borehole data shows continuation of various geological units along the Saxothuringian - 


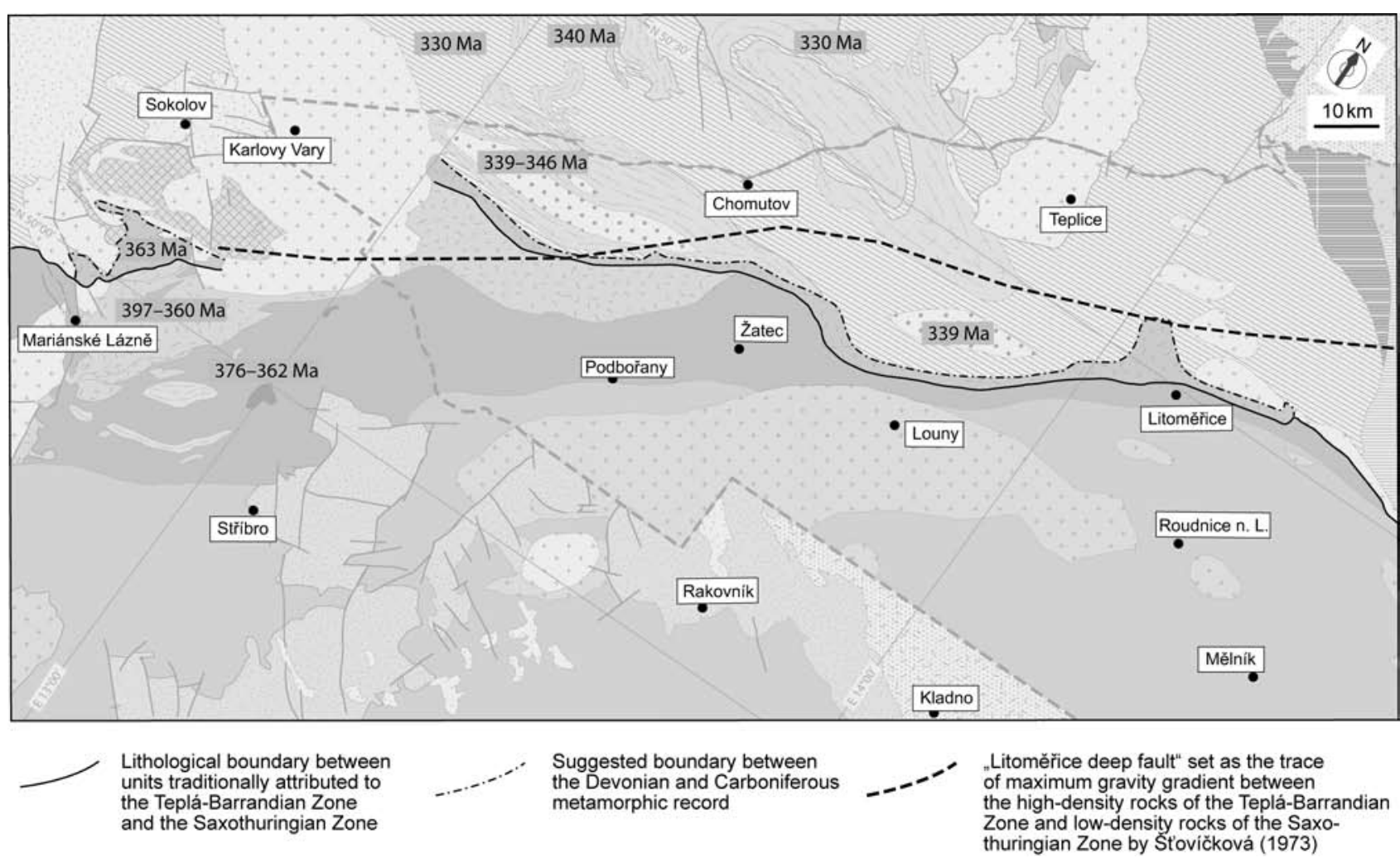

Fig. 6 Delimitation of geological (solid line) and geophysical (dashed line) boundary between units with an affinity to the Saxothuringian and the Teplá-Barrandian zones. Distribution of metamorphic ages of particular geological units in the study area suggests a "chronometamorphic" boundary (dot-and-dash line) between the Devonian and Carboniferous metamorphic record.

Teplá-Barrandian suture below the Late Carboniferous to Tertiary volcanosedimentary cover and thus allows the determination of the geological boundary between units that were traditionally attributed to the Saxothuringian Zone and those interpreted as a part of the Teplá-Barrandian Zone (Fig. 6). Comparison of the geophysical and the borehole data shows that the gravity boundary is shifted towards the northwest with respect to the actual geological boundary (Fig. 6; see also Švancara et al. 2008) suggesting an apparent presence of denser Teplá-Barrandian rocks below the covered part of the eastern margin of the Saxothuringian Zone. Similar shift was reported by Babuška et al. (2007) for the mantle lithosphere and attributed to its detachment from the rigid upper crust.

Existing metamorphic and geochronological data from outcropping equivalents of the covered geological units in the area of the Eger Graben suggest a complex assemblage of crustal segments metamorphosed at various depths and temperature regimes in two well-constrained and nonoverlapping temporal periods of the Variscan orogeny. Although there are several models attempting to explain Variscan tectonometamorphic evolution of the Erzgebirge Complex (Matte 1998; O'Brien 2000; Willner er al. 2000, 2002; Konopásek and Schulmann 2005; Babuška et al. 2010), the tectonic evolution between the Devonian exhumation of the high-grade Teplá-Barrandian margin and the Carboniferous collision involving exhumation of Lower Carboniferous diamond-bearing rocks, mafic eclogites and high-pressure granulites remains unclear. The apparent complexity in geological and temporal evolution of the western margin of the Bohemian Massif suggests that any acceptable model of its tectonic evolution must also involve critical evaluation of structural, petrological and geochronological record in small-scale units along the Saxothuringian - Teplá-Barrandian boundary.

Acknowledgements. We express our thanks to A. Willner for critical comments to an early version of the manuscript, as well as to J. Fiala, V. Babuška, U. Kroner and one anonymous reviewer for their careful reviews. We also highly appreciate efficient editorial handling by J. Žák and V. Janoušek. This study was supported by the Ministry of Education, Youth and Sports of the Czech Republic through the Scientific Centre "Advanced Remedial Technologies and Processes" (identification code 1M0554). JK acknowledges the financial support of the Grant Agency of the Charles University (project no. B-GEO-270/2006). 


\section{References}

BABušKa V, Plomerová J (2008) Control of paths of Quaternary volcanic products in western Bohemian Massif by rejuvenated Variscan triple junction of ancient microplates. Stud Geophys Geod 52: 607-629

Babuška V, Plomerová J, Fischer T (2007) Intraplate seismicity in the western Bohemian Massif (central Europe): a possible correlation with a paleoplate junction. J Geodyn 44: 149-159

BabušKa V, Plomerová J, Vecsey L (2008) Mantle fabric of western Bohemian Massif (central Europe) constrained by $3 \mathrm{D}$ seismic $\mathrm{P}$ and $\mathrm{S}$ anisotropy. Tectonophysics 462 : 149-163

Babuška V, Fiala J, Plomerová J (2010) Bottom to top lithosphere structure and evolution of western Eger Rift (Central Europe). Int J Earth Sci 99: 891-907

Beard BL, Medaris LG, Johnson CM, Jelínek E, Tonika J, RiciPUTI LR (1995) Geochronology and geochemistry of eclogites from the Mariánské Lázně Complex, Czech Republic: implications for Variscan orogenesis. Geol Rundsch 84: 552-567

BlížKovský M, Mašín J, Mátlová E, Mitrenga P, Novotný A, Pokorný L, Rejl L, Šalanský K (1994) Linear structures in the Czechoslovak part of Bohemian Massif derived from geophysical data. In: BuchA V, BLížKovský M (eds) Crustal Structure of the Bohemian Massif and West Carpathians. Academia, Prague, pp 323-328

Bowes DR, Aftalion M (1991) U-Pb zircon isotopic evidence for Early Ordovician and Proterozoic units in the Mariánské Lázně Complex, Central European Hercynides. Neu Jb Mineral, Mh 7: 315-326

Bowes DR, vAN BREEMEN O, Hopgood AM, JELÍNEK E (2002) ${ }^{40} \mathrm{Ar} /{ }^{39} \mathrm{Ar}$ isotopic evidence for mid-Devonian postmetamorphic pegmatite emplacement in the Mariánské Lázně Complex, Bohemian Massif, Central European Hercynides. Neu Jb Mineral, Mh 10: 445-457

ChÁB J, Stráník Z, Eliáš M (2007) Geological map of the Czech Republic 1 : 500 000. Czech Geological Survey, Prague

Chaloupský J (1973) The basement of the Cretaceous and the Permo-Carboniferous of northern Bohemia. Geol Rundsch 62: 581-594

Chudomel J, Jakeš O, Jihlavec F, Klímková V, Novák J, Ondrák J, Cimbalník V, Šustr I, Vašinová J (1983) Report on reflection seismic and gravity surveys in the Roudnice, Mšeno, Česká Kamenice, Mnichovo Hradiště and Krkonoše basins in the years 1981-1982. Unpublished manuscript, Geofyzika Brno. Archive of the Czech Geological Survey, Prague, pp 1-176 (in Czech)

Dallmeyer RD, Urban M (1998) Variscan vs. Cadomian tectonothermal activity in northwestern sectors of the Teplá-Barrandian zone, Czech Republic: constraints from ${ }^{40} \mathrm{Ar} /{ }^{39} \mathrm{Ar}$ ages. Geol Rundsch 87: 94-106
Dörr W, Fiala J, Vejnar Z, Zulauf G (1998) U-Pb zircon ages, geochemistry and structural development of metagranitoids of the Teplá Crystalline Complex - evidence for pervasive Cambrian plutonism within the Bohemian Massif (Czech Republic). Geol Rundsch 87:135-149

Dörr W, Zulauf G, Fiala J, Franke W, Vejnar Z (2002) Neoproterozoic to Early Cambrian history of an active plate margin in the Teplá-Barrandian unit - a correlation of U-Pb isotopic-dilution-TIMS ages (Bohemia, Czech Republic). Tectonophysics 352: 65-85

FRANKE W (1984) Variszischer Deckenbau im Raume der Münchberger Gneismasse - abgeleitet aus der Fazies, Deformation und Metamorphose im umgebenden $\mathrm{Pa}-$ läozoikum. Geotekt Forsch 68: 1-253

FrANKE W (1989) Tectonostratigraphic units in the Variscan Belt of Central Europe. In: DALLMEYER RD (ed.) Terranes in Circum-Atlantic Paleozoic orogens. Geological Society of America Special Papers 230: 67-90

FRANKE W (2000) The mid-European segment of the Variscides: tectonostratigraphic units, terrane boundaries and plate tectonic evolution. In: Franke W, HAAK V, Oncken O, TANner D (eds) Orogenic Processes: Quantification and Modelling in the Variscan Belt. Geological Society of London Special Publications 179: 35-61

FRANKe W, Stein E (2000) Exhumation of high-grade rocks in the Saxo-Thuringian belt: geological constraints and geodynamic concepts. In: Franke W, HAAK V, ONCKEN O, TANNER D (eds) Orogenic Processes: Quantification and Modelling in the Variscan Belt. Geological Society of London Special Publications 179: 337-354

Holub V, PešEK J (1992) Upper Carboniferous and Permian. In: ChlupÁČ I, ŠTORCH P (eds) Regional Subdivision of the Bohemian Massif on the Territory of the Czech Republic. Čas Mineral Geol 37: 257-275(in Czech)

Hoth K, Wasternack J, Berger HJ, Breiter K, Mlčoch B, Schovánek P (1995) Geologische Karte Erzgebirge/ Vogtland 1 : 100 000. Sächsisches Landesamt für Umwelt und Geologie, Freiberg

Hradecký P, Adamová M, Bohdánek P, Elznic A, Godány J, Hrazdíra P, Kotková J, Manová M, Mlčoch B,

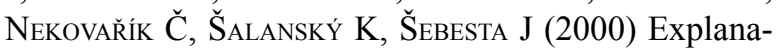
tion to $1: 25000$ geological map of the Czech Republic 11-222 Kadaň. Czech Geological Survey, Prague

JINDŘICH V (1971) New views in tectonic significance of platform sediments in the Bohemian Massif, Czechoslovakia. Geol Soc Am Bull 82: 763-768

KACHLík V (1993) The evidence for Late Variscan nappe thrusting of the Mariánské Lázně Complex over the Saxothuringian Terrane (W. Bohemia). J Czech Geol Soc 38: 46-58

KlÁPovÁ H, KonopáseK J, Schulmann K (1998) Eclogites from the Czech part of the Erzgebirge: multi-stage metamorphic and structural evolution. J Geol Soc, London 155: $567-583$ 
KonopÁseK J (1998) Formation and destabilization of the high pressure assemblage garnet-phengite-paragonite (Krušné Hory Mountains, Bohemian Massif): the significance of the Tschermak substitution in the metamorphism of pelitic rocks. Lithos 42: 269-284

Konopásek J, Schulmann K (2005) Contrasting Early Carboniferous field geotherms: evidence for accretion of a thickened orogenic root and subducted Saxothuringian crust (Central European Variscides). J Geol Soc, London 162: 463-470

Konopásek J, Schulmann K, Lexa O (2001) Structural evolution of the central part of the Krušné Hory (Erzgebirge) Mountains in the Czech Republic - evidence for changing stress regime during Variscan compression. J Struct Geol 23: 1373-1392

Kopecký L, SATtRan V (1966) Buried occurrences of pyrope-peridotite and structure of the crystalline basement in the extreme SW of the České středohoří Mountains. Krystalinikum 4: 65-86

Kopecký L, ChlupÁčová M, Klomínský J, Sokol A (1997) The Čistá-Jesenice pluton in western Bohemia: geochemistry, geology, petrophysics and ore potential. Sbor Geol věd, Ložisk geol mineral 31: 97-127

Kossmat F (1927) Gliederung des varistischen Gebirgsbaues. Abhandl Sächs Geol Landes 1: 1-39

KotKovÁ J (1993) Tectonometamorphic History of Lower Crust in the Bohemian Massif: Example of North Bohemian Granulites. Czech Geological Survey Special Papers 2: 1-42

KotKovÁ J, Kröner A, Todt W, Fiala J (1996) Zircon dating of north Bohemian granulites, Czech Republic: further evidence for the Lower Carboniferous high-pressure event in the Bohemian Massif. Geol Rundsch 85: 154-161

Kreuzer H, Vejnar Z, Schüssler U, Okrusch M, Seidel E (1992) K-Ar dating in the Teplá-Domažlice Zone at the western margin of the Bohemian Massif. In: KUKAL $Z$ (ed.) Proceedings of the $1^{\text {st }}$ International Conference on the Bohemian Massif, Prague, Czechoslovakia. Czech Geological Survey, Prague, pp 168-175

KroHe A (1996) Variscan tectonics of central Europe: postaccretionary intraplate deformation of weak continental lithosphere. Tectonics 15: 1364-1388

KRÖNER A, WiLLNER AP (1998) Time of formation and peak of Variscan HP-HT metamorphism of quartz-feldspar rocks in the central Erzgebirge, Saxony, Germany. Contrib Mineral Petrol 132: 1-20

Malkovský M (1987) The Mesozoic and Tertiary basins of the Bohemian Massif and their evolution. Tectonophysics 137: 31-42

Malkovský M, Benešová Z, ČAdeK J, Holub V, Chaloupský J, Jetel J, Müller V, Mašín J, TÁsler R (1974) Bohemian Cretaceous Basin and its basement. Czech Geological Survey, Prague, pp 1-262, 26 appendix folders (in Czech with English and German abstracts)
Malkovský M (1985) Geology of the North-Bohemian Brown Coal Basin and the surrounding area. Czech Geological Survey, Prague, pp 1-424, 48 appendix folders (in Czech with English abstract)

Matte P (1986) Tectonics and plate-tectonics model for the Variscan belt of Europe. Tectonophysics 126: 329-332

Matte P (1998) Continental subduction and exhumation of HP rocks in Paleozoic orogenic belts: Uralides and Variscides. GFF 120: 209-222

Matte P, Maluski H, Rajlich P, Franke W (1990) Terrane boundaries in the Bohemian Massif: result of large-scale Variscan shearing. Tectonophysics 177: 151-170

Mísař Z, Dudek A, Havlena V, Weiss J (1983) Geology of ČSSR - Bohemian Massif. SPN, Prague, pp 1-336 (in Czech)

MLČOCH B (2003) Character of the contact between the Saxothuringian and Teplá-Barrandian Unit. Geolines 16: 75

MLČOCH B, MARTíneK K (2002) Tectonosedimentary evolution of NW Bohemia based on the digital elevation model of crystalline basement and Upper Paleozoic strata: preliminary results. Geolines 14: 67

MlČ́ch B, Schulmann K (1992) Superposition of Variscan ductile shear deformation on pre-Variscan mantled gneiss structure (Catherine dome, Erzgebirge, Bohemian Massif). Geol Rundsch 81: 501-513

Mlčoch B, Breiter K, Chlupáčová M, Holub FV, Kotková J, Martínek K, Mašek J, Opluštil S, Pertoldová J, Rajchl M, Schulmannová B, TOMas R, Ž́̇́ČEK V (2001) Research on crystalline formations in deep structures beneath the Doupovské hory Complex and its broad surroundings - final report. Technical report, Czech Geological Survey, Prague, pp 1-122 (in Czech)

Mlčoch B, Adamová M, BŘízová E, Godány J, Holub FV, Hrazdíra P, KonopáseK J, KopaČKová V, KrupičKa J, Rajchl M, Rapprich V, Schovánek P, Skácelová D, Skácelová Z, ŠEbesta J, Vondrovic L (in press) Explanatory text to $1: 25000$ geological map of the Czech Republic 11-444 Klášterec nad Ohří. Czech Geological Survey, Prague (in Czech)

O'Brien P (2000) The fundamental Variscan problem: high-temperature metamorphism at different depths and high-pressure metamorphism at different temperatures. In: Franke W, HaAK V, Oncken O, Tanner D (eds) Orogenic Processes: Quantification and Modelling in the Variscan Belt. Geological Society of London Special Publications 179: 369-386

PAŠEK J, URBAN M (1990) The tectonic evolution of the Plzeň basin (Upper Carboniferous, West Bohemia): a review and reinterpretation. Folia Mus Rer Natur Bohemia Occid Geol 32: 3-56

Pešek J, Opluštil S, Kumpera O, Holub V, Skoček V, Dvořák J, Prouza V, Tásler R (1998) Paleogeographic atlas, Late Paleozoic and Triassic formations, Czech 
Republic. Czech Geological Survey, Prague, pp 1-56, 41 appendix folders

Pharaoh TC (1999) Palaeozoic terranes and their lithospheric boundaries within the Trans-European Suture Zone (TESZ): a review. Tectonophysics 314: 17-41

Pietzsch K (1914) Tektonische Probleme in Sachsen. Geol Rundsch 5: 161-174

Plomerová J, Achauer U, Babuška V, Vecsey L, BoheMIA WorkING Group (2007) Upper mantle beneath the Eger Rift (Central Europe): plume or asthenosphere upwelling? Geophys J Int 169: 675-682

RajChl M, UličnÝ D, Grygar R, Mach K (2009) Evolution of basin architecture in an incipient continental rift: the Cenozoic Most Basin, Eger Graben (Central Europe). Basin Res 21: 269-294

Rötzler K, Schumacher R, Maresch WV, Willner AP (1998) Characterisation and geodynamic implications of contrasting metamorphic evolution in juxtaposed highpressure units of the western Erzgebirge. Eur J Mineral 10: $261-280$

Sattran V, VÁnĚ M (1964) Phyllite series with metabasites at the eastern flank of the Eger Crystalline Complex near Kadaň. Čas Mineral Geol 9: 281-286 (in Czech with German summary)

Sedlák J, Gnojek I, Scheibe R, Zabadal S (2009) Gravity response of igneous rocks in the northwestern part of the Bohemian Massif. J Geosci 54: 325-342

Schmädicke E, Okrusch M, Schmidt W (1992) Eclogitefacies rocks in the Saxonian Erzgebirge, Germany: high pressure metamorphism under contrasting $\mathrm{P}-\mathrm{T}$ conditions. Contrib Mineral Petrol 110: 226-241

Schovánek P, Adamová M, Breiter K, Burda J, Cajz V, Elznic A, Fürych V, Godány J, KoŘÁn V, Manová M,

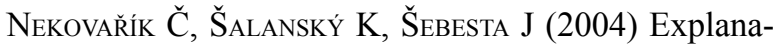
tion to $1: 25000$ geological map of the Czech Republic 02-321 Dubí and 02-143 Cínovec. Czech Geological Survey, Prague, pp 1-84 (in Czech)

Schulmann K, Mlčoch B, Melka R (1996) High-temperature microstructures and rheology of deformed granite, Erzgebirge, Bohemian Massif. J Struct Geol 18: 719-733

ŠPIČÁKová L, UličnÝ D, KoudelKová G (2000) Tectonosedimentary evolution of the Cheb Basin (NW Bohemia, Czech Republic) between Late Oligocene and Pliocene: a preliminary note. Stud Geophys Geod 44: 556-580

ŠŤoví̌́Ková N (1973) Deep-fault tectonics and its relation to endogenous geological processes. Academia, Prague, pp 1-198

Švancara J, Havír J, ConRad W (2008) Derived gravity field of the seismogenic upper crust of SE Germany and West Bohemia and its comparison with seismicity. Stud Geophys Geod 52: 567-588

Tichomirowa M, Whitehouse MJ, Nasdala L (2005) Resorption, growth, solid state recrystallization, and annealing of granulite facies zircon - a case study from the Central Erzgebirge, Bohemian Massif. Lithos 82: 25-50

Timmermann H, Štědrá V, Gerdes A, Noble SR, Parrish RR, DöRR W (2004) The problem of dating high-pressure metamorphism: a U-Pb isotope and geochemical study on eclogites and related rocks of the Mariánské Lázně Complex, Czech Republic. J Petrol 45: 1311-1338

UličnÝ D, Martínek K, GrYgar R (2002) Syndepositional geometry and post-depositional deformation of the Krkonoše Piedmont Basin: a preliminary model. Geolines 14: 101-102.

UličnÝ D, Špičáková L, Grygar R, Svobodová M, Čech S, LAURIN J (2009a) Palaeodrainage systems at the basal unconformity of the Bohemian Cretaceous Basin: roles of inherited fault systems and basement lithology during the onset of basin filling. Bull Geosci 84: 577-610

UličnÝ D, Laurin J, ČECH S (2009b) Controls on clastic sequence geometries in a shallow-marine, transtensional basin: the Bohemian Cretaceous Basin, Czech Republic. Sedimentology 56: 1077-1114

VeJNAR Z (1982) The regional metamorphism of psammiticpelitic rocks in the Domažlice area. Sbor geol Věd, Geol 37: 9-70 (in Czech with English summary)

Venera Z, Schulmann K, KRöNer A (2000) Intrusion within a transtensional tectonic domain: the Čistá granodiorite (Bohemian Massif) - structure and rheological modelling J Struct Geol 22:1437-1454

VRÁNA S, ŠTĚDRÁ V (1997) Geological model of western Bohemia related to the KTB borehole in Germany. Sbor geol Věd, Geol 47: 1-240

Werner O, LipPolt HJ (2000) White mica ${ }^{40} \mathrm{Ar} /{ }^{39} \mathrm{Ar}$ ages of Erzgebirge metamorphic rocks: simulating the chronological results by a model of Variscan crustal imbrication. In: Franke W, HaAK V, OnCKen O, TANNER D (eds) Orogenic Processes: Quantification and Modelling in the Variscan Belt. Geological Society of London Special Publications 179: 323-336.

WiLlner AP, Krohe A, Maresch WV (2000) Interrelated $\mathrm{P}-\mathrm{T}-\mathrm{t}-\mathrm{d}$ paths in the Variscan Erzgebirge Dome (Saxony, Germany): constraints on the rapid exhumation of high-pressure rocks from the root zone of a collisional orogen. Int Geol Rev 42: 64-85

Willner AP, Sebazungu E, Gerya TV, Maresch WV, Krohe A (2002) Numerical modelling of PT-paths related to rapid exhumation of high-pressure rocks from the crustal root in the Variscan Erzgebirge Dome (Saxony/ Germany). J Geodyn 33: 281-314

Závada P, Schulmann K, Konopásek J, Ulrich S, Lexa O (2007) Extreme ductility of feldspar aggregates - melt enhanced grain boundary sliding and creep failure: rheological implications for felsic lower crust. J Geophys Res - Solid Earth 112: B10210

Zoubek V, Ambrož V, Batatka B, Fiala F, Holubec J, Hoth K, Jetel J, KoláŘová M, Kopecký L, Lorenz W, 
Myslil V, Odehnal L, Polák A, Sládek J, Steinocher V, Šmíd B, VÁcl J, VRBA J (1963) Explanatory text to $1: 200000$ geological map of ČSSR M-33-XIII K. Vary. Czech Geological Survey, Prague, pp 1-290 (in Czech)

Zulauf G (1997) Von der Anchizone bis zur Eklogitfazies: angekippte Krustenprofile als Folge der Cadomischen und variscischen Orogenese im Teplá-Barrandium (Böhmische Masse). Geotekt Forsch 89: 1-302

Zulauf G, Dörr W, Fiala J, Kotková J, Maluski H, VALVERDE-VAQUeRo P (2002) Evidence for high-tempera- ture diffusional creep preserved by rapid cooling of lower crust (North Bohemian shear zone, Czech Republic). Terra Nova 14: 343-354

ŽÁČEK V, СНÁB J (1993) Metamorphism in the Teplá Upland, Bohemian Massif, Czech Republic (preliminary report). Bull Czech Geol Surv 68: 33-37

Ž́̇́ J, Kratinová Z, Trubač J, Janoušek V, Sláma J, Mrlina $\mathrm{J}$ (in press) Structure, emplacement and tectonic setting of Late Devonian granitoid plutons in the Teplá-Barrandian unit, Bohemian Massif. Int J Earth Sci, doi: 10.1007/ s00531-010-0565-7 